\title{
Patronage or Signaling: How Mayors Use City Payroll to Stay in Office
}

\begin{abstract}
Several studies on municipal hiring decisions have indicated that when a city's payroll grows, its mayor's re-election prospects are likely to improve. It is not clear, however, if such an effect is attributable to patronage-driven, or signaling-driven, behavior of the incumbents. The difference is important: patronage leads to inefficient public administration, while signaling can produce political business cycles. In this paper, I propose some key electoral implications of patronage-driven and signaling-driven hiring, and verify them with data on local elections in Bulgaria (2015 and 2011) and in Poland (2014). I find that a large municipal workforce has a negative overall effect on mayors' re-election. Importantly, the impact of city payroll varies with incumbents' partisanship (strongly negative for mayors representing the economic right, neutral for independent mayors, positive for ex-communist mayors) and does not depend on the duration of incumbent's tenure. These findings strongly support the patronage-driven explanation of Eastern Europe's local political economy.
\end{abstract}

Santrauka: Moksliniai tyrimai suponuoja teigiamą viešojo sektoriaus darbuotojų, dirbančių savivaldybėje, poveikị mero perrinkimui. Vis dėlto nėra aišku ar tokị poveikị lemia „balsų pirkimas" savivaldybèje įdarbinant mero rèmèjus, ar signalizavimas, t.y. viešojo sektoriaus paslaugų bei užimtumo didinimas artẻjant savivaldos rinkimams. Atsakymas ị šị klausimą turi ekonominių pasekmių. „Balsų pirkimas“ lemia nenašų viešojo sektorius darbą, o signalizavimas politinius verslo ciklus. Šiame darbe iškeliamos keturios politinès (rinkiminès) „balsų pirkimo“ ir signalizavimo implikacijos, kurių veikimas patikrinamas su savivaldos rinkimų Bulgarijoje (2015 m. ir 2011 m.) bei Lenkijoje (2014 m.) duomenimis. Tyrimo rezultatai rodo, kad viešojo sektoriaus darbuotojų skaičius savivaldybẻje daro bendrai neigiamą poveiki mero perrinkimo galimybėms. Svarbu tai, kad šis poveikis stipriai kinta su mero partiškumu (neigiamas laisvą rinką propaguojančių partijų merams, neutralus nepartiniams merams ir teigiamas buvusių komunistinių partijų merams), bei nepriklauso nuo mero buvimo poste trukmès. Šie rezultatai stipriai palaiko teigini, kad Rytų Europos savivaldoje veikia „balsų pirkimo" politinè ekonomija.

Keywords: Patronage, signaling, local elections, municipal employment, partisanship, Bulgaria, Poland 


\section{Introduction}

In this paper, I explore the implications of municipal employment on the re-election prospects of incumbent mayors. A number of authors have studied the reverse causal relationship: how incumbents' electoral calculations influence municipal hiring (Trebbi et al. 2008; Alesina et al. 2007; Enikolopov 2007; Alesina et al. 2001; Alesina et al. 2000; Coate and Morris 1995). Their models generally assume that incumbents reap electoral rewards from hiring representatives of loyal voter groups. Sieg and Wang (2013) corroborate this view, demonstrating the beneficial "muscle effect" that endorsement by a municipal workers' union has on election outcomes of US mayoral races. The strength of such an effect is proportional, among other things, to the number of municipal employees.

Labonne (2016) provides an alternative to this patronage-driven view, arguing that a large municipal workforce could benefit an incumbent as a signal of the incumbent's competence. A high number of city workers may signify a low joblessness rate or a wide scope of public services. By observing these outcomes, voters perceive the incumbent to be competent and deserving of reelection, even if the voters themselves (or their family members) are not employed by the city. Following this line of reasoning, Clark and Milicent (2011) propose that incumbent mayors may expand public-sector employment beyond the efficient level in order to improve the "quality of local life" and to please the electorate.

While these studies have provided reasons to expect a positive effect of municipal employment on reelection of mayors, it remains less clear which mechanism - patronage-driven or signaling-driven - is responsible for creating the effect. The answer to this question has real economic consequences. If mayors benefit from patronal hiring, the numbers of long-term city workers and their remuneration (depending on the bargaining power of municipal unions) should swell to inefficient levels (Alesina et. al. 2001). If mayors use public employment to signal their competence, they might accomplish this goal by expanding short-term rather than long-term employment, thereby creating city-level political business cycles (Labonne 2016).

In what follows, I propose testable electoral effects of municipal workforces, both in the patronage-driven and in the signaling-driven hiring environment. In the presence of patronage-driven hiring environment, robust municipal employment should mostly benefit left-wing mayors, while harming the prospects of right-wing incumbents. Also, the duration of a mayor's tenure should have no moderating effect on the relationship between the size of a municipal labor force and the re-election of an incumbent. Conversely, if the signaling-driven explanation of mayoral reelection is correct, then an incumbent's partisan identity should not matter: a large municipal workforce should benefit incumbents of all political affiliations. Also, public sector 
employment should benefit first-term incumbents more so than their more seasoned counterparts. I evaluate these implications empirically using data on the reelection of incumbent mayors in Eastern Europe. For reasons explained in a later section of this paper, this region offers a useful setting for testing propositions about city-level elections.

In the following section of this paper I elaborate the reasoning behind electoral implications of signaling-driven and patronage-driven hiring policies. In the next section I explain the choice of data for verification of the theoretical implications as well as the reasoning behind empirical models and report the results of regression analyses. I conclude by discussing empirical findings and their implications for the type of Eastern Europe's municipal political economy.

\section{Theoretical Framework}

\section{The Patronage-driven Environment}

In this section I modify Enikolopov (2007), who assumes that a municipal electorate consists of several factions. These factions may differ by income, ethnicity or other characteristics, but their members have an equal appetite for employment in the public sector. City jobs made available to members of factions in exchange for their electoral support represent patronage, and in turn, the value generated by these jobs will not cover the cost of remuneration.

An incumbent will staff municipal positions with representatives of loyal factions so long as the electoral benefit of their support (and the support of their family members) outweighs the electoral cost of inefficient provision of public services. Assuming that voters are uncertain about the costs of public services, incumbents can go unpunished for expanding a municipal workforce for long periods of time (until the state of their city's finances is revealed, which could result from, for instance, insolvency of the administration).

As an electoral instrument, patronal employment is superior to, say, commitment to a particular policy. A promise to implement a policy favored by an incumbent's loyal factions amounts to cheap talk, simply because the incumbent can renege post-election. On the other hand, hiring members of loyal factions prior to election solves this commitment problem, as civil servants are difficult to fire and can make downsizing politically costly.

The second commitment problem standing in the way of patronal hiring has to do with the loyalty of voters. If an incumbent is as (un)likely to downsize city workers as a successful challenger would, recipients of patronage have no incentive to support the incumbent in the privacy of the voting booth. A challenger, however, may find the costs of firing city workers offset by the benefits of staffing municipal positions with members of own loyal factions. Beneficiaries of patronage, then, have an incentive to keep their end of the 
bargain with the incumbent. They vote to keep the challenger out of office in order to preserve the continued flow of benefits afforded by an incumbent's past hiring decisions.

Such a patronage-driven environment produces several testable political implications. First, the partisan identity of a mayor should have no bearing on the relationship between municipal payroll and election outcomes. Since all voter factions equally value access to patronage jobs, all mayors should derive similar electoral outcomes from staffing municipal positions with loyalists. The assumption of voters' equal taste for patronage, however, is quite restrictive; Hibbs (1977) and Carlsen (1997) noted that different voter factions may take different views of policy outcomes, such as the deficit and unemployment. The low-income factions, for example might appreciate access to lucrative city jobs and a wide offer of public services in general, while the wealthy might be less keen on accessing municipal jobs and more interested in limiting the range of public services.

Assuming at least one voter faction (faction A) is interested in the downsizing of a city's apparatus yields partisan distinctions in the electoral effects of the municipal workforce. Faction A rewards its incumbents not for patronal hiring but for pruning the city payroll. This gives mayors representing faction A an incentive to fire some city-workers but not to replace them with own loyalists. Mayors representing factions seeking access to patronal jobs might also fire city workers, but - importantly - they would seek to replace these workers with their own loyalists.

Under the circumstances, an incumbent representing faction A does best by firing the number of municipal workers desired by faction A. Such a move gives a strong incentive for city-workers - those fired and those still on municipal payroll - to vote against the incumbent. And yet, the mayor representing faction A would do even worse by not downsizing. The municipal workers would still vote against the mayor in order to minimize the hazard of losing their jobs in the subsequent term. The members of faction A, however, might be less motivated to vote for an incumbent that has not implemented their desired policy.

The electoral prospects of an incumbent representing faction A, then, suffer as the number of municipal workers rises. Mayors that represent factions seeking patronal employment can, on the other hand, benefit from large numbers of city workers, as long as they staff the municipal positions with loyalists. The first electoral implication of a patronage-driven political economy, therefore, is:

Implication 1: In a patronage-driven political economy, the size of the municipal workforce will improve the electoral prospects of incumbents who represent factions favoring an expansion of the municipal payroll, while hurting the electoral prospects of incumbents representing factions that favor a reduction of the city's administration. 
Next, the effect of the municipal workforce on a mayor's reelection should not vary by the duration of the incumbent's time in office. Hiring or retaining city-workers represents a vote-buying transaction that an incumbent may or may not implement again in the future. For example, if city finances are in a particularly precarious position, a mayor might downsize the workforce, regardless of having expanded it in the past. In fact, repeated patronage-driven expansions of city payroll make future downsizing more likely. An incumbent, then, does not build a reputation with their own voter factions by expanding their city's workforce during previous terms.

Holders of patronal jobs know, however, that their incumbent is less likely to lay them off than a successful challenger would be. As previously mentioned, a successful challenger has an incentive to open lucrative city positions for personal loyalists by firing incumbent's patronal appointees. Beneficiaries of patronage, then, vote strictly to keep the challenger out of office, and not because of their incumbent's reputation. In such a scenario a mayor's time in office has no impact on the relationship between the number of city workers and incumbent's electoral prospects. A first-term mayor, having fired previous incumbent's supporters and staffed municipal positions with members of own friendly factions, should seek a consecutive term as successfully as a multi-term incumbent. The second electoral implication of a patronagedriven political economy, therefore, is:

Implication 2: In a patronage-driven political economy, the relationship between the size of a municipal workforce and an incumbents' re-election does not vary with the duration of the incumbents' time in office.

\section{The Signaling-driven Environment}

In this section I follow Labonne (2016), who views municipal employment not as patronage, but as an instrument with which incumbents influence the local economy. Hiring city workers affects the "quality of local life", directly through the services provided by these workers, and indirectly through the stimulating effect that wages of municipal employees exert on the demand in the economy. Incumbents decide on the size of the municipal workforce subject to budget constraints and upon consideration of their own electoral prospects. Voter factions differ in their preferences over policy (including preferences for the size of the municipal payroll), yet all voters equally value mayors' competent handling of the economy. Citizens lack complete knowledge of incumbents' competence, yet they can observe changes in local economic conditions and use such observations to extract indirect information about a mayor's competence. Voters are uncertain about the costs of an incumbent's policies. 
In such a setting incumbents have an incentive to signal their competence to voters by decreasing unemployment (Nordhaus 1975) and by increasing public spending (Rogoff 1990, Rogoff and Siebert 1988) prior to an election. After an election, however, budget constraints force mayors to scale back their expansive policies (Eslava 2006). Signaling-based behavior, then, is liable to produce local electoral business cycles. An emerging empirical literature indicates that local incumbents in diverse political environments engage in visible public spending prior to elections (see Labonne (2016) for a review of the literature).

The evidence on signaling-driven growth in municipal jobs is less readily available, with one study from the Philippines reporting increases in shortterm public employment before elections (Labonne 2016.) The expansion in short-term contracts suggests incumbents' signaling (rather than patronal) motivations. Short-term hiring would not solve commitment problems that stand in the way of vote-buying by incumbents (Enikolopov 2007) because short term contracts could be easily discontinued post-election. A boost in short-term employment, however, could signal incumbent's competence by stimulating the local economy. Also, easy termination of short term contracts after an election is consistent with a mayor's need to obey budget constraints.

If incumbents use hiring to signal their competence, the political implications of their behavior should be starkly different from the ones observed in a patronage-driven environment. First, in a signaling-driven political economy, a mayor's partisanship should matter little in terms of whether the boosting or stifling of public employment influences their re-election chances. Unlike patronage, signaling does not aim to influence the votes of municipal workers. An incumbent, then, benefits from the signaling effects of a large municipal workforce even if city-workers are not particularly fond of their mayor.

For example, an incumbent representing a faction opposed to the expansion of municipal payroll may not expand the city's administration or even downsize it, thus earning no sympathies among city workers. As long as the remaining public servants perform their jobs, however, they continue emitting a signal about the mayor's quality. Assuming constant efficiency of city workers, the activities of a diminished municipal workforce will send a weaker signal about the competence of a mayor. The incumbent then has to choose whether the benefit of satisfying a friendly voter faction outweighs the cost of weakening the signal of competence. Importantly, incumbents experiencing the most electoral success will be the ones that manage to please their voter faction while preserving the largest possible number of city workers (and the strongest signal of their competence). The third electoral implication of a signalingdriven political economy, therefore, is:

Implication 3: In a signaling-driven political economy, the size of a municipal workforce has a positive effect on incumbents' re-election prospects, irrespective of mayors' partisan identities. 
Next, large public sector employment should help the electoral prospects of first-term incumbents more than those of their seasoned counterparts. The latter should have had more opportunities to signal their competences to the voters; hence for them the marginal benefit of an additional signal should generally be weaker. Labonne (2016) indirectly corroborates this implication by demonstrating that public sector employment in the Philippines expands most in the regions where first or second-term incumbents seek reelection. The fourth electoral implication of a signaling-driven political economy, therefore, is:

Implication 4: In a signaling-driven political economy the size of a municipal workforce has a weaker positive effect on incumbents' re-election prospects, as the duration of incumbents' term in office increases.

\section{Empirical Verification}

I verify the electoral implications of patronage-based and signaling-based political economy with data from municipal elections in Bulgaria (local elections of 2015 and 2011) and Poland (local election of 2014). Eastern Europe offers a useful setting for testing propositions about city-level elections. First, a number of Eastern European countries elect mayors according to similar rules (majority runoff with the first round of voting taking place on the same day as elections to municipal councils). These polls yield strong variation in incumbents' outcomes. In Bulgaria (2015), for example, incumbents lost $41 \%$ of the time (Centralna izbiratelna komisija 2016). The number of public servants in Eastern Europe's municipalities also varies widely. In 2011 the range of the share of jobs in public administration, defense, education, human health and social work extended from 11.91\% in Pazardzhik, Bulgaria (Nacionalen statističeski institut 2016) to 40.37\% in Przemyśl, Poland (Eurostat 2016).

Multi-party systems present in Eastern European countries might incentivize incumbents to campaign on easily differentiable partisan policy platforms (e.g. more city services v. greater efficiency of city services). This feature of political competition allows testing of propositions about partisan influence on the relationship between municipal workforce and the re-election of incumbent mayors. Significantly, the political debate about the optimal size of municipal workforce might be more relevant in Eastern Europe after the 2008-2010 recession than in Western Europe. During the recession, local and regional governments in Western Europe increased running expenses, including essential public services, in response to an increase in popular demand (Council of European Municipalities and Regions 2009). The regional and local expenditures for similar services in Eastern Europe, however, have failed to increase or, in some instances, have even fallen (Ibid). Given the 
continued economic hardships in the region, political debates on the future level of expenditures (and public employment) can be expected in Eastern European mayoral elections.

In both Bulgaria and Poland, mayors possess considerable discretion in determining the scope and the composition of municipal workforces. In Poland hiring of city workers is formally a prerogative of municipal councils (Puszkarska 2014). Mayors, however, have full discretion in hiring municipal support staff (Szumowski 2008). More importantly, Polish law defines city councils as "subsidiary bodies of mayors" (Matys 2016). Mayors chair city councils and set their agenda (Ibid). Considering the fact that they usually represent some of the largest political factions within the councils, mayors can wield considerable impact on councils' hiring decisions. While city jobs are formally filled through open contests (Skwarło 20012), the Polish media have revealed mayor's knack for custom tailoring job requirements to meet characteristics of desired candidates (Klinowski 2015; Tracz 2011). Notably, the media have also written about large-scale downsizing of municipal workforces in Polish towns, placing the responsibility squarely on the mayors (Pawlik 2016; Lewkowicz 2015; Drewka 2014; Pankiewicz 2011). While heads of Bulgarian cities do not chair municipal councils, the Law on Local Government and Local Administration provides mayors with a right to appoint an dismiss "heads and employees of the municipal administration" (Asociacia na gradovete i regionite 2016). Such a prerogative gives mayors considerable influence on the overall municipal hiring decisions. Much like their Polish counterparts, Bulgarian mayors are free to hire municipal support staff (Ibid).

Finally, Bulgaria and Poland represent different paths of economic and political development, both during Communism and during the post-communist transformation. Prior to World War II Polish politics displayed a high degree of political mobilization among the bourgeoisie and the peasants as well as a moderately professional civil service (Kitschelt 1999). Bulgaria, meanwhile, displayed features of a patrimonial polity with lower political mobilization and a less efficient public administration (Ibid). Also, in Bulgaria Communist regime survived largely from exports of primary goods (Robinson 2003). Such an undiversified source of income made the state highly autonomous from the society. These differences lead to the emergence of distinct types of Communist regimes in the two countries. Compared to their Polish comrades, Bulgarian Communist leaders relied more on repression than on cooptation of the opposition, and tolerated a lower diversity of opinion within the party (Kitschelt 1999).

Consequently, post-communist politics in Bulgaria have lacked what Grzymała-Busse (2006) has called robust competition. Unable to force excommunists out of power in 1991, the Bulgarian opposition faced bleak prospects as the Bulgarian Socialist Party retained control of resources and agenda setting. Opposition, therefore, has been unclear (because of internal 
fragmentation), not credible (due to the lack of resources) and not contentious (due to the influence of the ex-communists on the media) (Ibid). In Poland, on the contrary, a clear, credible, and contentious competition between the rebranded Communist successors and parties emerging from the former opposition marked the first decade of post-communist politics (Ibid). On the one hand, such a difference in the robustness of political competition might mean greater competitiveness of Polish elections and, therefore, a more extensive use of patronage-based or signaling-based strategies by incumbents in that country than in Bulgaria. Such a finding would indicate a limited generalizability of the results even in the context of Eastern Europe. On the other hand, finding similar electoral effects of municipal workforce in both of these dissimilar countries would attest to the robustness and generalizability of the results.

\section{Empirical models}

I verify the propositions of this paper by estimating the following models with data from Bulgaria (local elections of 2015 and 2011) and Poland (local elections of 2014).

$\begin{array}{lll}\text { DIF_R } 1=\alpha+\beta 1 * \text { RATIO }+\beta 2 * \text { UNEMP }+\beta 3 * \text { SCAND }+\beta 3 * \text { BG }+\varepsilon & \text { (equation 1) } \\ \text { DIF_R } 1=\alpha+\beta 1 \text { RATIO }+\beta 2 \text { LFT }+\beta 3 \text { INTER_LR }+\beta 4 \text { UNEMP }+\beta 5 \text { SCAND }+\beta 6 B G+\varepsilon & \text { (equation 2) } \\ \text { DIF_R1 } & =\alpha+\beta 1 \text { RATIO }+\beta 2 \text { RGT }+\beta 3 \text { INTER_RR }+\beta 4 \text { UNEMP }+\beta 5 \text { SCAND }+\beta 6 \text { BG }+\varepsilon & \text { (equation 3) } \\ \text { DIF_R1 } & =\alpha+\beta 1 \text { RATIO }+\beta 2 \text { IND }+\beta 3 \text { INTER_IR }+\beta 4 \text { UNEMP }+\beta 5 \text { SCAND }+\beta 6 B G+\varepsilon & \text { (equation 4) } \\ \text { DIF_R1 }=\alpha+\beta 1 \text { RATIO }+\beta 2 \text { TEN }+\beta 3 \text { INTER_TR }+\beta 4 \text { UNEMP }+\beta 5 \text { SCAND }+\beta 6 B G+\varepsilon & \text { (equation 5) } \\ \text { DIF_R1 }=\alpha+\beta 1 \text { RATIO }+\beta 2 \text { BG }+\beta 3 \text { INTER_BR }+\beta 4 \text { UNEMP }+\beta 5 \text { SCAND }+\varepsilon & \text { (equation 6) }\end{array}$

Dependent variable DIF_R1 represents the difference between the share of the vote garnered by an incumbent mayor and the closest challenger (in the case of incumbent's victory) or the winning candidate (in the case of incumbent's loss) in the first round. In three cases from the 2011 Bulgarian local election, independent incumbents decided not to seek reelection and did not endorse a successor. I have excluded these three observations (municipalities of Veliko Tarnovo, Silistra and Ruse in 2011) as they do not produce a value of the dependent variable. In cases where partisan incumbents did not seek reelection, I have replaced them with the candidates of their political parties. It is reasonable to treat such candidates as incumbents as they had usually held senior positions in municipal administration and had benefited from outgoing mayors' endorsements.

I analyze vote differentials only in round-one of elections, because $40 \%$ of mayors in the sample did not participate in the runoff (most of them winning a majority of the vote in round-one). Excluding these observations would deplete the already-modest number of observations, making estimation of 
round-two vote-differentials meaningless. Also, I have chosen to forego an analysis of the final vote differentials because the political environment in multi-candidate round-one is considerably different from that in a twocandidate runoff. The data for this variable are available on the websites of Centralna izbiratelna komisija (2016) and Państwowa komisja wyborcza (2016).

Variable RATIO represents jobs in "public administration, defense, education, human health and social work" (Eurostat 2016) as a share of total jobs in the municipality prior to election (2014 and 2010 in Bulgaria and 2011 in Poland). Values of RATIO are available for all Bulgarian cities and for 52 (out of 68) Polish cities. This measure of municipal workforce is clearly problematic, as soldiers, teachers, physicians and social workers do not work directly for a municipality. Absent a better alternative, however, RATIO should still possess explanatory power in relation to DIF_R1. First, municipal authorities in Bulgaria and in Poland influence the budgets and the leadership selection of municipal educational and social-work structures (Gazeta prawna 2012; Iliev 2012). Mayors, then, should be able to influence hiring decisions of these structures. Next, I exclude from the analysis the capital cities of Sofia and Warsaw, since their RATIO would likely be inflated by national-level bureaucrats, not accountable to mayors. Finally, if the number of jobs in positions outside of municipal control (say jobs in defense) varies independently of municipal hiring patterns, their inclusion in the values of RATIO while increasing "noise" levels - should not bias the value of estimators. I expect RATIO to have a generally positive effect on incumbents' margin of victory, save for the exceptions discussed in the previous section. Data for this variable have been obtained from Eurostat's "Cities (Urban Audit) Database" (for Poland) and from Nacionalen statističeski institut (2016).

Categorical variables LFT, RGT and IND indicate incumbent's partisanship. LFT $=1$ stands for mayors nominated by Communist successor parties (The Bulgarian Socialist Party and Poland's Democratic Left Alliance). Leftist incumbents represent $22 \%$ of the sample. $\mathrm{RGT}=1$ indicates that a mayor represents an economically rightist party (GERB - Citizens for European Development of Bulgaria and Civic Platform in Poland). Right-wing incumbents constitute $32 \%$ of the sample. IND $=1$ represents an incumbent, campaigning independently from a national political party, usually with personal electoral committee. Independent incumbents represent $31 \%$ of the sample. Multiplicative terms INTER_LR, INTER_RR and INTER_IR indicate interactions between mayor's partisanship and variable RATIO. The data for variables LFT, RGT and IND are taken from Centralna izbiratelna komisija (2016) and Państwowa komisja wyborcza (2016).

I assume that incumbents from Communist successor parties take positions in favor of expanding municipal workforce, while economically rightist mayors take opposite positions. In the case of Bulgaria I base this assumption on data 
from Manifesto Project Database (2016) that shows GERB and Bulgarian Socialist Party consistently taking positions at the opposite extremes of the Economy (State-Market) issue dimension. Poland's major political parties, in the meantime, do not display consistent differences on the said dimension (Ibid). Yet in the past decade Democratic Left Alliance has emerged at the only political party representing left-leaning voters (Holm-Hansen 2011) while Civic Platform has been identified by several authors as the most market-friendly major political force in Poland (Ibid; Riishøj 2010; Sczerbiak 2008). If the patronage-driven explanation of local political economy is correct, I expect RATIO to have a positive (negative) effect on re-election of LFT (RGT) mayors. Since independent mayors may take positions both for and against a large municipal workforce, RATIO should have no systematic effect on their electoral success in a patronage-driven environment. In a signaling-driven environment, however, incumbents' partisanship generally should have no significant effect on their re-election prospects.

Variable TEN represents the duration of an incumbent's tenure, while INTER_TR is an interaction of incumbent's years in office with RATIO. In a patronage-based political economy an incumbent's tenure should have no significant influence on the relationship between RATIO and electoral outcomes, while in a signaling-based environment duration of mayor's tenure should dampen the positive effect of RATIO on the margins of mayor's victory. Data for variable TEN can be found at Centralna izbiratelna komisija (2016) and Państwowa komisja wyborcza (2016).

A control variable UNEMP represents the joblessness rate in a city. With many people unemployed, incumbents are more likely to lose their positions regardless of their efforts at signaling or patronage-peddling. Data for UNEMP are taken from Główny urząd statystyczny (2016) and Nacionalen statističeski institut (2016). Another categorical control variable, SCAND, represents the involvement of an incumbent in a corruption scandal. Much like the joblessness rate, allegations of corruption complicate incumbents' electoral prospects, regardless of their economic policy. I have obtained data for SCAND by reviewing Bulgarian and Polish press (Konkurent 2014; Dnevnik 2013; Mediapool 2013; Mitov 2013). Finally, BG is a categorical variable indicating Bulgaria and INTER_BG is its associated multiplicative term. Statistical insignificance of BG and INTER_BG would attest to the robustness and generalizability of the results.

I estimate equations $1-10$ using Ordinary Least Squares (OLS) regression. Due to extremely small time-variation I treat all data as cross-sectional. Residuals of all estimations are homoscedastic and follow normal frequency distributions. Equations containing interaction terms, however, display high Variance Inflation Factors, associated with these variables, and with variable representing joblessness rate. I correct collinearity by standardizing variables RATIO and UNEMP. The results of Ramsey's RESET test indicate that linear 
regression models are adequate for the data: variance in the dependent variable could not be explained better by including non-linear transformations in the equations. Finally, estimates of equations should not suffer from simultaneous causation bias, since predictors temporally precede the dependent variable that varies strongly from period to period: correlation coefficient between DIF_R1 values of Bulgaria's 2011 and 2015 local elections equals $0.22(\mathrm{p}=0.2 \overline{8})$.

\section{Results}

The estimation results seen in Table 1 lend strong support for the patronagebased interpretation of the relationship between the number of public servants and the re-election of mayors. Equations 1, 2, 4 and 5 indicate a negative overall effect that RATIO has on incumbents' margin in the first round of an election. Such a finding contradicts the literature that implies a positive overall effect of RATIO on DIF_R1. The negative relationship, however, can be reconciled with the modified view of patronage-driven political economies presented in this paper. Partisan influences may produce an overall positive or negative relationship between RATIO and DIF_R1 with some parties benefitting from, and others handicapped by, a large number of public servants. Estimates of equations 2 and 3 support this perspective of a patronage-driven political economy: for LFT mayors, RATIO has a positive effect on DIF_R1, while the effect is negative for incumbents representing the economic right.

Table 1. Results ( $p$ values in parentheses)

\begin{tabular}{|c|c|c|c|c|c|c|}
\hline Predictor & Equation 1 & Equation 2 & Equation 3 & Equation 4 & Equation 5 & Equation 6 \\
\hline CONSTANT & $\begin{array}{c}20.2388 \\
(<0.0001)\end{array}$ & $\begin{array}{c}25.9209 \\
(<0.0001)\end{array}$ & $\begin{array}{c}17.0087 \\
(<0.0001)\end{array}$ & $\begin{array}{l}19.6205 \\
(0.0001)\end{array}$ & $\begin{array}{l}20.0532 \\
(0.0012)\end{array}$ & $\begin{array}{c}19.3167 \\
(<0.0001)\end{array}$ \\
\hline UENMP & $\begin{array}{c}-0.31219 \\
(0.8994)\end{array}$ & $\begin{array}{l}1.53091 \\
(0.4941)\end{array}$ & $\begin{array}{c}-0.24934 \\
(0.9137)\end{array}$ & $\begin{array}{c}-0.29009 \\
(0.9076)\end{array}$ & $\begin{array}{c}-0.16791 \\
(0.9476)\end{array}$ & $\begin{array}{c}-0.54798 \\
(0.8258)\end{array}$ \\
\hline SCAND & $\begin{array}{c}-12.4169 \\
(0.1307)\end{array}$ & $\begin{array}{c}-17.5588 \\
(0.0193)\end{array}$ & $\begin{array}{c}-16.5733 \\
(0.0314)\end{array}$ & $\begin{array}{c}-12.6341 \\
(0.1349)\end{array}$ & $\begin{array}{c}-12.1083 \\
(0.1466)\end{array}$ & $\begin{array}{c}-12.3728 \\
(0.1327)\end{array}$ \\
\hline RATIO & $\begin{array}{c}-6.74536 \\
(0.0163)\end{array}$ & $\begin{array}{c}-8.00185 \\
(0.0026)\end{array}$ & $\begin{array}{c}-3.25235 \\
(0.2833) \\
\end{array}$ & $\begin{array}{c}-6.66476 \\
(0.0640)\end{array}$ & $\begin{array}{c}-8.88382 \\
(0.0981) \\
\end{array}$ & $\begin{array}{c}-4.39545 \\
(0.2616)\end{array}$ \\
\hline LFT & & $\begin{array}{c}-28.885 \\
(<0.0001)\end{array}$ & & & & \\
\hline INTER_LR & & $\begin{array}{l}17.2193 \\
(0.0130)\end{array}$ & & & & \\
\hline RGT & & & $\begin{array}{c}20.6 \\
(<0.0001)\end{array}$ & & & \\
\hline
\end{tabular}




\begin{tabular}{|c|c|c|c|c|c|c|}
\hline INTER_RR & & & $\begin{array}{c}-11.7044 \\
(0.0279)\end{array}$ & & & \\
\hline IND & & & & $\begin{array}{l}1.19461 \\
(0.8414)\end{array}$ & & \\
\hline INTER_IR & & & & $\begin{array}{c}0.088246 \\
(0.9870)\end{array}$ & & \\
\hline TNR & & & & & $\begin{array}{c}0.047413 \\
(0.9281)\end{array}$ & \\
\hline INTER_TR & & & & & $\begin{array}{c}0.269442 \\
(0.6331)\end{array}$ & \\
\hline$B G$ & $\begin{array}{l}1.14627 \\
(0.8091)\end{array}$ & $\begin{array}{l}1.68848 \\
(0.6898)\end{array}$ & $\begin{array}{c}-5.29163 \\
(0.2547)\end{array}$ & $\begin{array}{l}1.65174 \\
(0.7628)\end{array}$ & $\begin{array}{l}1.04868 \\
(0.8359)\end{array}$ & $\begin{array}{l}2.28219 \\
(0.6437)\end{array}$ \\
\hline INTER_BR & & & & & & $\begin{array}{c}-4.39522 \\
(0.3934)\end{array}$ \\
\hline N & 100 & 100 & 100 & 100 & 100 & 100 \\
\hline Adjusted $\mathrm{R}^{2}$ & 0.066348 & 0.260786 & 0.204314 & 0.046720 & 0.048723 & 0.063737 \\
\hline Omnibus $p(F)$ & 0.032139 & $<0.0001$ & 0.000110 & 0.105793 & 0.098749 & 0.046896 \\
\hline Akaike criterion & 917.0695 & 895.5901 & 902.9519 & 921.0222 & 920.8118 & 918.2905 \\
\hline White's test $p$ & 0.351824 & 0.755476 & 0.491912 & 0.257875 & 0.436373 & 0.537889 \\
\hline Normality of residual $p$ & 0.189668 & 0.65587 & 0.39247 & 0.907824 & 0.955999 & 0.924001 \\
\hline RESET test $p(F)$ & 0.642765 & 0.896423 & 0.594944 & 0.498097 & 0.889557 & 0.722081 \\
\hline
\end{tabular}

The ex-communist mayors lose by large margins in municipalities with low and moderate values of RATIO. As the share of public servants rises, so too do the chances of a victory by mayors nominated by Communist successor parties. For example, in municipalities characterized by a mean value of RATIO (20.44\%), vote differentials of mayors representing Communist successor parties are on average $28.89 \%$ lower than vote differentials of other incumbents (equation 2). An increase of public servants' share by one standard deviation (7.5\%) above the mean, however, more than halves the deficit of ex-communist mayors. When RATIO rises to two standard deviations above the mean, vote differentials of Communist successor incumbents are on average $5.55 \%$ greater than vote differentials of other mayors. Alternatively, an increase in the share of public servants by one standard deviation above the mean causes all incumbents, except for the ex-communists, an average drop of approximately $8 \%$ in their vote differentials. For LFT-nominated mayors, however, such an increase in the share of public servants results in a boost to their average vote differential by approximately $9 \%$. 
The performance of incumbents representing the economic right follows an exactly opposite pattern (equation 3). RGT mayors do well in municipalities with moderate and low shares of civil servants. In a hypothetical municipality characterized by the mean RATIO value an average vote margin of a marketfriendly incumbent is $20.6 \%$ greater than an average margin of other mayors. An increase of RATIO by one standard deviation above the mean cuts the RGT incumbent's advantage to $8.9 \%$. When the share of public servants reaches two standard deviations above the mean, vote differentials of incumbents representing the economic right become on average $2.8 \%$ lower, compared to vote differentials of other mayors. Alternatively, all mayors, except for the economic rightists, experience no statistically significant effect of the share of public servants on their electoral outcomes. The vote difference of incumbents nominated by the RGT parties, in the meantime, plummets by an average $11.7 \%$ due to an increase in the share of public servants by one standard deviation above the mean.

Independent mayors, as expected, do not differ from the overall population in terms of the effect that the municipal workforce has on their chances of re-election (equation 4). Such strong findings of partisan effects on the relationship between RATIO and DIF_R1 allow rejecting the model of signaling-based political economy, while lending firm support to the patronagebased alternative. The fact that the length of an incumbent's tenure has no effect on the relationship between the share of public servants and electoral outcomes further challenges the signaling-based view. Estimates of equation 5 show that an increase of one standard-deviation above the mean value of RATIO reduces first-term incumbents' vote differential by an average of $8.88 \%$, and that this effect does not change significantly as mayor's experience grows.

Consistent with expectations, an incumbent's involvement in a corruption scandal has a significant and strongly negative electoral effect (equations 2 and 3). The effect of unemployment, however, lacks statistical significance in all equations. Finally, estimates of equation 6 indicate robustness and generalizability of the results since the relationship between RATIO and DIF_R1 is not significantly different in Bulgaria and in Poland.

\section{Conclusion}

The economic effects of a municipal workforce vary, largely depending on the political considerations of incumbent mayors. If incumbents benefit from patronal hiring, the numbers of long-term city workers and their remuneration (depending on bargaining power of municipal unions) should swell to inefficient levels (Alesina et. al. 1999). If mayors use public employment to signal their competence, they might accomplish this goal by expanding short-term rather than long-term employment, thus creating city-level political business cycles (Labonne 2016). 
In this paper I have tested which of these two mechanisms is more likely to occur. I derived four electoral implications of municipal workforce in patronage-driven and in signaling-driven environments, and tested them with data from recent local elections in Bulgaria and Poland. The empirical evidence showed strong partisan effects, but no incumbency effect, on the relationship between the share of public servants and incumbent's electoral outcomes. These findings lend clear support for the patronage-based explanation of mayors' hiring practices.

My findings, however, suggest an optimistic conclusion that vote-peddling is not profitable for most political parties in Eastern Europe. While large numbers of public servants have helped re-election efforts of the incumbents nominated by Communist successor parties, the effect of civil servants on the average vote differential of all the incumbents has been negative. This result has been driven not only by mayors representing the economic right but also by the independents who do not differ systematically from the overall population of incumbents. Absent significant increases in patronage-inducing factors, such as income inequality or ethnic fragmentation (Trebbi et al 2008; Alesina et al 2001), the economic effects of patronal hiring should be expected in a limited range of Eastern Europe's municipalities.

\section{References}

Alesina, A. et al. 2001. Redistribution through Public Employment: The Case of Italy. IMF Staff Papers. 48(3), pp.447-73.

Alesina, A. et al., 2000. Redistributive Public Employment. Journal of Urban Economics. 48(2), pp.219-41.

Asociacia na gradovete i regionite [online]. 2016. Available from: $<$ http://www.abgr. org/abgr/laws_ZMSMA.htm>. [Accessed 2016].

Carlsen, F., 1997. Counterfiscal Policies and Partisan Politics: Evidence from Industrialized Countries. Applied Economics. 29, pp.154-51.

Centralna izbiratelna komisija [online]. 2016. Available from: <https://www.cik.bg/>. [Accessed 31 October 2016].

Clark, A. E. and Milicent, C., 2011. Public employment and political pressure: The case of French hospitals. Journal of Health Economics. 30(5), pp.1103-12.

Coate, S. and Morris, S., 1995. On The Form of Transfers to Special Interests. Journal of Political Economy. 103(6), pp.1210-35.

Council of European Municipalities and Regions, 2009. Impact of the Economic and Financial Crisis on Local and Regional Authorities. Second Survey. CCRE-CEMR: Brussels. 
Dnevnik, 2013. Lečkov e opravdan okončatelno po deloto za oščetjavane na obščina Sliven. Dnevnik.bg. n.d., Issue n.d., pp.n.d.. Available from: <http://www. dnevnik.bg/bulgaria/2013/11/21/2187515_lechkov_e_opravdan_okonchatelno_ po_deloto_za/ $>$. [Accessed: 31 October 2016].

Drewka, W., 2015. Kartuzy. Burmistrz redukuje etaty, a radni chcą wiedzieć, gdzie te oszczędności?. [online]. Express Kaszubski. Available from: <http:// expresskaszubski.pl/aktualnosci/2015/11/kartuzy-burmistrz-zwalnia-a-radnipytaja-gdzie-te-oszczednosci>. [Accessed 05 December 2016].

Enikolopov, R., 2007. Politicians, bureaucrats and patronage. (Job market paper). Harvard University, Cambridge, MA. Available from: <http://isites.harvard.edu/ fs/docs/icb.topic222612.files/Ruben_lunch.pdf>. [Accessed: 31 October 2016].

Eslava, M., 2006. The Political Economy of Fiscal Policy: Survey. (583). Inter-American Development Bank, Washington, DC. Available from: <http://www.iadb. org/res/publications/pubfiles/pubWP-583.pdf>. [Accessed: 31 October 2016].

Eurostat, 2004. Database - Cities (Urban Audit). Office for Official Publication of the European Communities: Luxembourg.

Główny urzad statystyczny. Portal Informacyjny [online], 2016. Available from: <http:// stat.gov.pl/>. [Accessed 2016].

Grzymala-Busse, A., 2006. Authoritarian Determinants of Democratic Party Competition: The Communist Successor Parties in East Central Europe. Party Politics. 12(3), pp.415-37.

Hibbs, D., 1977. The Political Parties and Macroeconomic Policy. American Political Science Review. 7, pp.1467-87.

Holm-Hansen, J., 2011. Continuity and Change in Polish Party Politics since 1989. In: Bakke, E. and Peters, I., ed. 20 Years since the Fall of the Berlin Wall: Transitions, State Break-Up and Democratic Politics in Central Europe and Germany, Cambridge, England: Intersentia, pp269-84.

Iliev, H., 2012. Kmetovete iskat da uvolnjat direktori. [online]. Marica. Available from: $<$ http://www.marica.bg/кметовете-искат-да-уволняват-директори-news88699. html>. [Accessed 05 December 2016].

Kitschelt, H., 1999. Accounting for Outcomes of Post-Communist Regime Change: Causal Depth or Shallowness in Rival Explanations. In: Annual Meeting of the American Political Science Association, 31 August - 3 September, Atlanta, GA. pp. 1-52.

Konkurent, 2014. Vidinčani se sabirat pred sada na deloto na Gergo Gergov. Konkurent. bg. n.d., Issue n.d., pp.n.d.. Available from: <http://konkurent.bg/article/24457/ vidinchani-se-subirat-pred-suda-na-deloto-na-gergo-gergov $>$. [Accessed: 31 October 2016].

Labonne, J., 2016. Local political business cycles: Evidence from Philippine municipalities. Journal of Development Economics. 121, pp.56-62. 
Lewkowicz, H., 2015. Burmistrz Jarosławia rozpoczął zwolnienia pracowników. [online]. Nowiny24. Available from: <http://www.nowiny24.pl/wiadomosci/ jaroslaw/art/5814971,burmistrz-jaroslawia-rozpoczal-zwolnienia-pracownikow, id,t.html>. [Accessed 05 December 2016].

Manifesto Project Database [online], 2016. Available from: $<$ https://manifesto-project. wzb.eu/>. [Accessed 31 October 2016].

Matys, L., n.d.. Co to jest urząd gminy. [online]. Infor.pl Prawo. Available from: $<$ http://www.infor.pl/prawo/gmina/abc-gminy/98125,Co-to-jest-urzad-gminy. html>. [Accessed 05 December 2016].

Mediapool, 2013. Palna paraliza na mestnata vlast vav Varna: GERB se izmakva, re "vsičko zavisi ot kmeta". Mediapool.bg. n.d., Issue n.d., pp.n.d.. Available from: <http://www.mediapool.bg/palna-paraliza-na-mestnata-vlast-vav-varnagerb-se-izmakva-che-vsichko-zavisi-ot-kmeta-news203662.html>. [Accessed: 31 October 2016].

Mitov, B., 2013. Plovdivskijat apelativen sad osadi ekskmeta na Veliko Tarnovo. Mediapool.bg. n.d., Issue n.d., pp.n.d.. Available from: $<$ http://www.mediapool. bg/plovdivskiyat-apelativen-sad-osadi-ekskmeta-na-veliko-tarnovo-news212405. html>. [Accessed: 31 October 2016].

Nacionalen statističeski institut [online], 2016. Available from: <http://www.nsi.bg/ bg>. [Accessed 2016].

Nordhaus, W. D., 1975. The Political Business Cycle. Review of Economic Studies. 42(2), pp.169-90.

Pankiewicz, P., 2011. Brodnica. Burmistrz zwolnił dziesięciu pracowników. To jeszcze nie koniec. [online]. Gazeta Pomorska. Available from: <http://www.pomorska. pl/wiadomosci/brodnica/art/7202494,brodnica-burmistrz-zwolnil-dziesieciupracownikow-to-jeszcze-nie-koniec,id,t.html>. [Accessed 05 December 2016].

Państwowa komisja wyborcza [online], 2016. Available from: <http://pkw.gov.pl/>. [Accessed 2016].

Pawlik, P., 2016. Lędziny: protest w obronie pracowników magistratu. [online]. Onet. Ślask. Available from: <http://slask.onet.pl/ledziny-protest-w-obroniepracownikow-magistratu/3lgrg8 $>$. [Accessed 05 December 2016].

Plaszczyca, M., 2015. Desant z Krakowa w ratuszu. Burmistrz zatrudnia swoich. [online]. Wadowice24.pl. Available from: <http://www.wadowice24.pl/nowe/ polityka/1237-desant-z-krakowa-w-ratuszu-burmistrz-zatrudnia-swoich/1237desant-z-krakowa-w-ratuszu-burmistrz-zatrudnia-swoich.html $>$. [Accessed 05 December 2016].

Puszkarska, A., 2014. Warunki zatrudnienia pracownika gminy. [online]. Rzeczpospolita. Available from: <http://www.rp.pl/artykul/1137012-Warunki-zatrudnieniapracownika-gminy.html\#ap-1>. [Accessed 05 December 2016]. 
Riishøj, S., 2010. The Civic Platform in Poland-the first decade 2001-2011. (No. 24/2010). University of Southern Denmark, Odense, Denmark. Available from: <www. sdu.dk/-/media/files/om_sdu/institutter/.../sri civic platform_hjemmeside.pdf>. [Accessed: 31 October 2016].

Robinson, N., 2003. Communist and post-communist states, and path dependent political economy. (3). University of Limerick, Limerick. Available from: $<$ http://www.ul.ie/ppa/content/files/Robinson_communist.pdf $>$. [Accessed: 31 October 2016].

Rogoff, K., 1990. Equilibrium Political Budget Cycles. American Economic Review. 80, pp.21-36.

Rogoff, K. and Sibert, A., 1988. Elections and Macroeconomic Policy Cycles. The Review of Economic Studies. 55(1), pp.1-16.

Sczerbiak, A., 2008. The Birth of a Bipolar Party System or a Referendum on a Polarizing Government? The October 2007 Polish Parliamentary Election. Journal of Communist Studies and Transition Politics. 24(3), pp.415-43.

Sieg, H. and Wang, Yu, 2013. The impact of unions on municipal elections and urban fiscal policies. Journal of Monetary Economics. 60(5), pp.554-67.

Skwarło, R., 2012. Obowiązek przeprowadzenia naboru. [online]. Wspólnota. Available from: <http://www.wspolnota.org.pl/aktualnosci/aktualnosc/obowiazek-przeprowadzenia-naboru/>. [Accessed 05 December 2016].

Szumowski, S., 2008. Zasady zatrudniania pracowników w urzędach gmin i w jednostkach organizacyjnych gmin. [online]. BIP Urzędu Miejskiego w Bialej Piskiej. Available from: <http://bip.bialapiska.pl/index.php?wiad=2976>. [Accessed 05 December 2016].

Tracz, M., 2011. Burmistrz chciał zatrudnić swoich znajomych. [online]. TVN Warszawa. Available from: $<\mathrm{http}: / /$ tvnwarszawa.tvn24.pl/informacje,news,burmistrz-chcialzatrudnic-swoich-znajomych,26775.html>. [Accessed 05 December 2016].

Trebbi, F. et al., 2008. Electoral Rules and Minority Representation in U.S. Cities. The Quarterly Journal of Economics. 123 (1), pp.325-357.

\section{About Author}

\section{Vincentas VOBOLEVIČIUS}

$\mathrm{He}$ is an Associate Professor and Head of Economics and Politics Study Program at ISM University of Management and Economics. He specializes in political economy and post-communist transformations. 